\title{
A ReVIEW OF THE YeaR’s Publications in Robin HoOd ScHOLARSHIP
}

\author{
Mikee Delony \\ Abilene Christian University
}

Peer-reviewed Robin Hood scholarship published in 2015 includes two single-author books, two edited book chapters, and eight journal articles. These publications examine specific texts from the matter of Robin Hood, providing new approaches to familiar texts and further exploration of less-familiar materials. Many scholars also comment on the tradition's capacity for seemingly endless adaptation and highlight the similar ideological and political threads woven through the materials. Shining an academic light upon five centuries of Robin Hood texts that celebrate political resistance and public activism against oppression takes on new importance in light of contemporary global resistance to government overreach and systemic oppression.

Since Robin Hood scholarship also tends to resist categorization, I have loosely grouped these reviews by literary chronology and genre.

\section{GENERAL STUDIES}

In Reading Robin Hood: Content, Form, and Reception in the Outlaw Myth, ${ }^{1}$ Stephen Knight revisits the Robin Hood literary tradition from his position as one of the early pioneers in the field of Robin Hood studies. In his survey, which ranges from medieval oral ballads to twentyfirst film and television adaptations, Knight notes the multivalent, "unhierarchial, nonlinear" (10) nature of the tradition and suggests that Deleuze and Guattari's rhizomatic "model of multiplicity" (234) might best describe the "various, porous, [and] richly labile” legend (10). Writing that the Robin Hood tradition "renews itself in turns of current political forces and media of dissemination and consistently has as scant a respect for literary and formalistic authority as it has for social and legal forces of order" (253), Knight celebrates the characteristics that prevent the tradition from achieving canonical status at the same time they have remained relevant for centuries. The essays reviewed here are evidence of the truth in his statement.

In his second book of 2015, The Politics of Myth, ${ }^{2}$ Knight examines nine Western European mythical characters that, he argues, are still popular and relevant today. His chapter on Robin Hood is particularly useful for those who are new to Robin Hood studies. Describing the

\footnotetext{
${ }^{1}$ Stephen Knight, Reading Robin Hood: Content, Form, and Reception in the Outlaw Myth, Manchester Medieval Literature and Culture Series (Manchester: Manchester University Press, 2015). For more detailed reviews of this book see John Marshall, review of Reading Robin Hood: Content, Form, and Reception in the Outlaw Myth, by Stephen Knight, Arthuriana 26, no. 2 (2016): 141-43; and Sabina Rahman, "Knight: Reading Robin Hood,” Medievally Speaking, 6 November 2015, http://medievallyspeaking.blogspot.com/2015/11/knight-reading-robinhood.html.

${ }^{2}$ Steven Knight, The Politics of Myth (Carlton, AUS: Melbourne University Press, 2015), 88-112.
} 
medieval outlaw as a "socially resistant figure" (94), Knight briefly surveys familiar texts from each century, broadly noting changes and additions to the legend, and emphasizing its adaptability. He suggests that pre-nineteenth-century materials, particularly the eighteenthcentury broadside ballads, acted as "safety valve[s]" (100) for an increasingly revolutionary population, and he credits nineteenth-century texts-novels, poems, and biographies by authors such as Sir Walter Scott and Thomas Love Peacock, among others, with "shaping a version of the hero and his activities that has kept him vigorously alive ... in [popular culture] when other medieval popular heroes faded away" (101). Moreover, Knight argues that twentieth-century film and television adaptations brought Robin Hood into the international spotlight. He concludes this chapter by reaffirming his thesis that although the details of the tale may change, Robin Hood consistently acts as a "natural, active, entertaining force against the oppressive officials who misuse the authority of higher forces" (112), a statement with which a few of his colleagues reviewed here will disagree.

\section{FifTEENTH-CENTURY BRITISH CHRONICLE TRADITION}

In "John Mair's Historiographical Humanism: Portraits of Outlaws, Robbers, and Rebels in his Historia Maioris Brianniae tam Angalie quam Scotiae (History of Greater Britain),"33 Alexander L. Kaufman examines the John Mair's 1521 text in the context of the medieval chronicle tradition, which he describes as "writing [that] describe[s] historical moments with a greater amount of elaboration, subjectivity, introspection, and sometimes, bias" (104). Crediting Mair with a "more nuanced elaboration," Kaufman first provides a thorough biographical sketch of the Scottish Mair's life, education, and prolific teaching and writing career, and places his account of three "transgressive figures" (115)—Robin Hood, William Wallace, and Jack Cade—within the context of Mair's own political and philosophical views, particularly his "nationalistic leanings and his own notions of humanism" (105). Noting that his "desire for balance, especially in political thought and action" (106) influences his representations of Robin Hood, Wallace, and Cade (106), Kaufman explains that for Mair, the connection between political and social events, his own "humanistic values" (106), and his judgment of the outlaws' status and purpose for their actions influence his definition of balance. In his section on the mythical Robin Hood, Mair follows the lead of previous chroniclers who progressively pushed Robin's timeline back from the early fourteenth-century reign of Edward III to the turn of the thirteenth-century reign of the notorious King John-1199-1216 - the era in which most post-medieval texts locate the legend. Additionally, Mair raises Robin's status and may have, according to Kaufman (and Knight and Ohlgren), based his version of Robin Hood on "Foulke fitx Waryn," an outlaw who lived during the reign of King John. After examining Mair's accounts of William Wallace, in which Kaufman comments that Mair raised the Scottish hero to "near mythical status" (110), and of Jack Cade and his 1450 rebellion, which Mair soundly condemns, Kaufman concludes that in addition to balance, "Mair's notion of political resistance is tied to a stratified political system" (114).

\footnotetext{
${ }^{3}$ Alexander L. Kaufman, “John Mair’s Historiographical Humanism: Portraits of Outlaws, Robbers, and Rebels in his Historia Maioris Brianniae tam Angalie quam Scotiae (History of Greater Britain), Enarratio 19 (2015): 10418.
} 
Wallace was "recognized” by the ruling class; however, Cade was a "shadowy figure . . . radical, contradictory, and ultimately dangerous" (114). And because the mythical Robin Hood figure Mair describes in his chronicle is English, is one who "took the life of no man, unless he either attacked them or offered resistance in defense of his property" (Mair, qtd in Kaufman 107), and is a leader of “some one hundred men," Robin Hood meets Mair's requirements for "balance” and thus warrants a benign characterization of this medieval outlaw. In this case, Kaufman writes that like Wallace, Robin Hood is “part of a glorified legendary past” (114).

\section{SIXTEENTH- AND SEVENTEENTH-CENTURY DRAMA ${ }^{4}$}

In "Political Fortunes of Robin Hood on the Early Modern Stage," 5 the early modern drama scholar Jean E. Howard reports that seven different Robin Hood plays appeared on stage in the last decade of the sixteenth-century, not including Shakespeare's As You Like It. ${ }^{6}$ Referencing the legend's flexibility, Howard describes the early modern adaptation of the popular hero to the stage as a period of "energetic shuffling and transposition of its elements and the addition of some new ones” (277). Additionally, Howard argues, theater-goers and producers participated in a shared theater culture in which the audience anticipated and enjoyed different versions of Robin Hood.

After briefly summarizing “the Matter of Robin Hood” (275) and emphasizing the myth’s association with "popular resistance, carnival, and rebellion ... [and] the greenwood" (273), Howard examines the remaining four extant Robin Hood plays as well as Shakespeare's As You Like It and, surprisingly, 1 Henry IV and 2 Henry IV, paying particular attention to gender construction and political arguments. Of particular interest to Robin Hood scholars is Howard's description of the less well-known Chronicle of King Edward, the First (1593) by George Peele, which is somewhat unique in Robin Hood literature because the famous outlaw is not a "person but a role inscribed in a book" (279, emphasis mine). Members of the court consult the book on stage as they perform the roles of Robin and his Merry Men. Howard comments, "rather than being one who uses disguise to fool abbots or the Sheriff of Nottingham, he is now the disguise that others wear" (279).

Howard's unusual reading of Henry IV is also worthy of attention. She suggests that Hal offers an "imaginative and daring engagement with the matter of Robin Hood" (284) and that Hal's "masculinity ... is a strange amalgamation of the tonalities that have variously accrued to

\footnotetext{
${ }^{4}$ Thank you to Joe Stephenson, a scholar of early modern drama and my colleague, for his assistance in my review of the Howard and Quarmby essays.

${ }^{5}$ Jean Howard, "Political Fortunes of Robin Hood on the Early Modern Stage” in Forms of Association: Making Publics in Early Modern Europe, Massachusetts Studies in Early Modern Culture, ed. Paul Yachnin and Marlene Eberhart (Amherst: University of Massachusetts Press, 2015), 272-88.

${ }^{6}$ Howard includes the following Robin Hood dramas in her analysis: The Comedy of George a Greene, performed at the Rose by Sussex's Men in 1593-94; George Peele's The Chronicle of King Edward the First, performed by the Admiral's Men throughout the 1590s; and Anthony Munday's 1598-1600 paired plays, The Downfall of Robert Earl of Huntington and The Death of Robert Earl of Huntington. Additionally, she reads William Shakespeare's As You Like It, and Henry IV, Part I and Part II as including substantial illusions to Robin Hood.
} 
the Robin Hood figure” (284). Moreover, she argues that at times he is a "chivalric hero," a "trickster leader of a homosocial band," or “a philosophical leader," and suggests that by casting Hal in both roles-urban outlaw and heir to the throne-Shakespeare blurs the line between the two, highlighting Hal's slippage into the liminal space between the world of the tavern (i.e., greenwood space) and of the court, or between the resistance and the crown (284). Howard concludes her thoughtful essay by referring to Robin Hood as an "exploitable resource ... whose political implications shifted and changed as dramatists” featured different aspects of the legend and "responded to the innovations of fellow dramatists" (287).

In order to make a twenty-first century social justice argument in “Bardwashing' Shakespeare: Food Justice, Enclosure, and the Poaching Poet,"7 Kevin A. Quarmby hijacks Shakespeare's allusions to Robin Hood's greenwood and his role as a social bandit in As You Like It in an attempt to provide evidence that bolsters Katherine Duncan-Jones' unflattering depiction of Shakespeare as a greedy, ambitious social climber in her 2001 biography, Ungentle Shakespeare: Scenes from His Life. ${ }^{8}$ By conflating Shakespeare's fictions with Duncan-Jones' account of his personal financial dealings, Quarmby argues that Shakespeare benefited from the Robin Hood mythology present in his play and that his fictional celebration of Robin Hood as social bandit and "proto food activist" (1) is hypocritical in light of Duncan-Jones' argument that Shakespeare had little regard for the starving poor. This essay is based on faulty scholarship; specifically, Quarmby reads Shakespeare's play as an intentionally misleading autobiography that Shakespeare uses as a cover for his own shady financial dealings. If indeed strong evidence exists that corroborates the Duncan-Jones account, then why use his fiction? Quarmby's use of As You Like It as a convenient, although anachronistic, vehicle for his own polemic attack on Shakespeare's alleged self-serving role in the sixteenth-century Enclosure Debates calls the entire argument into question.

\section{SEVENTEENTH- AND EIGHTEENTH-CENTURY BROADSIDE BALLADS}

The only ballad-focused essay published in 2015 is Alexander L. Kaufman's second publication, "A Desire for Origins: The Marginal Robin Hood of the Later Ballads."9 In this essay Kaufman calls attention to the marginalized seventeenth- and eighteenth-century Robin Hood broadside ballads in order to make a larger argument about the marginalization of Hood studies as a whole within the discipline of literary studies. Noting the "outsider, transgressive status" (51) of Robin Hood scholars and texts, Kaufman writes that he set out, like Robin Hood himself, “to 'right a wrong' and position these later, post-medieval texts as worthy of attention ... as works of medievalism ... [and as] valuable resources for those who seek

\footnotetext{
${ }^{7}$ Kevin A. Quarmby, “'Bardwashing' Shakespeare: Food Justice, Enclosure, and the Poaching Poet,” Journal of Social Justice 15 (2015): 1-21.

${ }^{8}$ Katherine Duncan-Jones, Ungentle Shakespeare, Scenes from His Life, Arden Shakespeare Library, (London: Arden/Bloomburg, 2001).

${ }^{9}$ Alexander L. Kaufman, “A Desire for Origins: The Marginal Robin Hood of the Later Ballads,” Studies in Medievalism XXIV: Medievalism in the Margins, ed. Karl Fugelso, Vincent Ferré, and Alicia C. Montoya, (Woodbridge, UK: D. S. Brewer/ Boydell \& Brewer, 2015): 104-18.
} 
Robin's outlaw origins in literature" (55). Noting that the medieval texts lack an origin story, he examines several post-medieval ballads that "present a multiplicity of origins, each unique yet each one clearly about Robin Hood." ${ }^{10}$ In addition to summarizing their plots, Kaufman traces each ballad's publication history through a number of seventeenth- and eighteenth-century Garlands. These ballads portray contrasting images of Robin Hood, including several that position the young Robin as part of the gentry class, often featuring his darker side reminiscent of his violence in Robin Hood and Guy of Gisborne. Even the gentrified Robin of Robin Hood's Birth, Breeding, Valour, and Marriage, heir to his uncle's manor and leader of his Sherwood Forest band, kills five yeomen in self-defense. However, Robin Hood's Progress to Nottingham presents the opposite extreme, a Robin Hood that Kaufman labels a "teenage psychopath" (59). When he encounters fifteen men while traveling to an archery contest in Nottingham, they mock him, and after he wins a wager that he cannot kill a deer at one hundred rod (550 yards) (59), they threaten him. In retaliation, he kills all fifteen men with his bow and arrow.

Kaufman's careful analysis of these origin ballads, particularly their noted contrasts between Robin's roles as gentrified man of the greenwood and as violent outlaw, supports his secondary argument about value of the tales' medievalism. Kaufman argues for the inclusion of these later ballads as important and useful literary texts, noting that although their "literary origins are from the Middle Ages ... [their] biological origins are works of pure medievalism" (62). Additionally, he convincingly maintains that writers of these ballads were "free" to create new narratives about Robin Hood's origins, and like Howard's argument about early modern drama, Kaufman maintains that "readers, then and now, continue to accept degrees of variation in Robin's personality and biography" (60).

\section{NINETEENTH-CENTURY NOVELS}

In "The Novelist, the Heiress, the Artisan, and the Banker: The Emergence of the Robin Hood Legend at Edwinstowe, c. 1819-1849," "11 David Crook details his historical and literary search for the source(s) of the connection between the Nottinghamshire village of Edwinstowe and the Robin Hood tradition, particularly the two famous oak trees-Major Oak and Robin's Larder-and Robin's marriage to Marian in the village church. Crook's detective work uncovers evidence hidden within the pages of four early nineteenth-century texts that settle the question of how and why Edwinstowe became an integral part of the Robin Hood legend centuries after its medieval origins. The authors and texts which Crook found most valuable in his research include Thomas Love Peacock's 1822 novel Maid Marian (the Novelist), Elizabeth Sarah Villa-Real Gooch's 1804 novel, Sherwood Forest: or Northern Adventure (the Heiress),

\footnotetext{
${ }^{10}$ Ballads that Kaufman examines in this essay include Robin Hood's Birth, Breeding, Valour, and Marriage; Robin's Progress to Nottingham; Robin Hood and the Forresters; A True Tale of Robin Hood. Robin Hood and Queen Catherine; Robin Hood's Golden Prize. Robin Hood and the Valiant Knight are alternate titles for Robin Hood and the Forresters.

${ }^{11}$ David Crook, "The Novelist, the Heiress, the Artisan, and the Banker: The Emergence of the Robin Hood Legend at Edwinstowe, c. 1819-1849,” Transactions of the Thoroton Society of Nottinghamshire 119 (2015): 169-81.
} 
Carter's 1850 travel guide to Sherwood Forest (the Banker). Each text added a crucial piece to Crook's puzzle. Additionally, he argues that these particular additions to the traditional legend arise in the early nineteenth century because Edwinstowe and Sherwood Forest were popular sites for tourists whose visits were inspired by the period's romantic novels, particularly Sir Walter Scott's Ivanhoe (1819). Crook's article provides fascinating insight into ways in which the Robin Hood legend grew and expanded throughout the centuries, continually incorporating new storylines while retaining the essence of the greenwood social bandit.

Stephen Basdeo's essay, "Radical Medievalism: Pierce Egan's the Younger's Robin Hood, Wat Tyler, and Adam Bell,"12 focuses, like Kaufman's, on marginalized texts and writers, in this case, the nineteenth-century novelist Pierce Egan the Younger. Basdeo examines three of Egan's outlaw novels along with their historical and cultural background and suggests that Egan's focus on medieval outlaws serves the political purpose of "highlight[ing] the plight of the poor and their need for political enfranchisement ... by presenting [these outlaws] as working class heroes who stood up for their political rights" (50).

Of interest for this review is Basdeo's section on Egan's novel, Robin Hood and Little John. He begins by highlighting the novel's prolific publishing history, beginning with its first publication in 1838 and continuing for more than 30 years in both England and France. Moreover, he also credits Walter Scott's 1819 novel, Ivanhoe, in this case, for the "notion that the Anglo-Saxons and the Normans were opposed to each other" (51). This antagonism is a concept that plays an important role in Egan's novel as well as in the politics of the Young England movement that, perhaps coincidentally, coincides with the period of the novel's publication. In Egan's Robin Hood, the titular hero demands that his fellow outlaws elect as him leader of the outlaw band rather than appointing him because of his higher social status. Basdeo responds to Robin Hood's out-of-character request with a rhetorical question: "what could have been more radical to Victorian readers than seeing people of lowly birth voting for their leader? Robin's election, furthermore, is based upon merit rather than his “"noble' birth” (52). Basdeo also explains that despite Robin's election, Egan's novels do not necessarily provide a "vision of a democratic society" (53) but rather use well-known anti-establishment characters such as Robin Hood to draw "attention to the problems in Britain's political system" (53) The outlaws in Egan's novels, Basdeo argues, are not criminals but vehicles that he uses to expose the "Old Corruption" (58) of the Normans and their self-serving politics. Basdeo concludes by pointing out that, unfortunately, Egan's contemporary reviewers did not recognize his political stance, perhaps, ironically, because the medieval settings were "too remote" (59) for early Victorian reviewers to recognize Egan’s critique of their own political situation.

\section{TWENTIETH- AND Twenty-First Century NOVEls, FiLMs, AND TELEVISION SERIES}

This final section reviews one essay that analyzes a number of novels and films as well three essays that focus on twentieth- and twenty-first century television series and films. Rob

\footnotetext{
${ }^{12}$ Stephen Basdeo, “Radical Medievalism: Pierce Egan’s the Younger’s Robin Hood, Wat Tyler, and Adam Bell,” Leeds Working Papers in Victorian Studies. Vol 15: Imagining the Victorian, ed. Lauren Padgett and Stephen Basdeo, (Leeds: LCVS, 2016), 49-65.
} 
Gossedge begins his chapter "'We Are Robin Hood': The Outlaw Tradition in Contemporary Popular Culture" 13 by reminding us that "[t]he Robin Hood tradition is always open to radical rewritings" (251). With the expectation that postmodern cultural changes, particularly "gender politics" and "an increased awareness of ethnic and religious conflict" may be evident in popular Robin Hood texts, Gossedge examines a selection of novels published between 1990 and 2010 and of visual media produced between 1984 and 2010. He limits his study to select feministand masculinist-authored novels, sequels, and visual texts that reference the crusades and include a Middle Eastern/Muslim character. ${ }^{14}$ Although he credits many feminist-authored novels and Robin Hood sequels with increasing gender equality overall and with consistently writing strong Marians, he finds that masculinist texts tend to return to the male-centric focus of the medieval ballads. He also notes that with the exception of some recognition for the Third Crusade, film and television adaptations remain "rigidly stuck in the twelfth century" (257). His analysis of the inclusion of Arabic-Muslim characters in film and television productions suggests some increased representation, particularly since beginning of US-led Middle-Eastern conflicts; nonetheless, he concludes that the Arab and Muslim roles are uneven and often stereotypical and shallow.

Throughout the essay, Gossedge expresses frustration with the failure of turn-of-thetwentieth-century Robin Hood texts to reflect the significant cultural and social changes of the period, in contrast with previous generations of writers who reframed Robin Hood materials in ways that critiqued and engaged with their own cultural conflicts and changes. Unlike Knight's optimistic assertion that Robin Hood "consistently acts as a "natural, active, entertaining force against the oppressive officials" (Politics of Myth 112), Gossedge writes that the final result of his immersion into relatively recent Robin Hood texts is the realization that despite the explosion of Robin Hood-themed materials created during political and socioeconomic conditions in which "the tradition typically flourishes" (251), the myth has increasingly "focused on the politics of the individuated self" and has "ceased to represent anything but the tamest resistance to authority" (252).

The following two essays analyze mid-twentieth-century film and television productions, and like Gossedge express similar disappointment with the increased emphasis Robin Hood retellings place on the American trait of individualism and their failure to represent the legend's signature resistance in any significant way. In "Reassessing Blacklist Era

13 Rob Gossedge, “'We Are Robin Hood': The Outlaw Tradition in Contemporary Popular Culture,” Medieval Afterlives in Contemporary Culture, ed. Gail Ashton, (London: Bloomsbury, 2015), 251-62.

${ }^{14}$ Gossedge references the following texts in his analysis: Robin McKinley's The Outlaws of Sherwood; Jennifer Roberson's, The Lady of the Forest; Gayle Feyrers’ The Thief's Mistress; Kathryn Lasky's Hawksmaid; Theresa Tomlinson's The Forestwife; Paul Storrie’s Robyn of Sherwood; Nancy Springers’ Rowan Hood; Disney’s Princess of Thieves; Dana Taylor's Royal Rebel; R. M. ArceJaegar’s Robin: Lady of Legend; A. C. Gaughen's Scarlett; Michael Cadnum's In a Dark Wood; Michael Morpurgo’s Outlaw; Stephen Lawhead's Hood; Steven McKay’s Wolf's Head; Kevin Reynold's Robin Hood: Prince of Thieves; Ridley Scott's 2010 Robin Hood; John Irvin’s 1991 Robin Hood; Douglas Fairbank’s 1922 Robin Hood; BBC’s Robin Hood series; Michael Praed's Robin of Sherwood series; BBC’s Maid Marian and Her Merry Men; and Mel Brook’s Robin Hood: Men in Tights. 
Television: Civil Libertarianism in You Are There, The Adventures of Robin Hood, and The Buccaneers," 15 Andrew Paul examines the little-known connection between the 1950s McCarthy trials and three popular 1950s BBC and CBS television series. Until this hidden story was brought to light by Michael Eaton in his 1991 film Fellow Traveller, few were aware that blacklisted American writers were hired under multiple pseudonyms to write for British television producers. Paul argues that although these blacklisted writers were hired to "challenge the dominant discourses of the cold war" (30), over time they adopted "a civil libertarian rhetoric that emphasized individual liberties over matters of social justice" (30).

Paul analyzes The Adventures of Robin Hood television series, which aired in the US and Britain in 1955-58 with "143 original episodes [that] would continue to be shown through the early sixties” (30). Writing under a number of pseudonyms, blacklisted writers Ring Lardner, Jr. and Ian McLellan Hunter believed that clandestine writing for television was a way to strike back against the ideology of the contemporary Red Scare; the Robin Hood trope of AngloSaxons suffering under the oppression of Norman invaders spoke "directly to the injustices of the Hollywood blacklist" (41). However, differences between the liberal socialist writers and the increasingly culturally and politically conservative audiences led to a television show that finds "solutions in a kind of populism that celebrates a mythic individualist idea" (42). Concluding that perhaps Robin Hood was an inappropriate vehicle for accomplishing the producers' and writers' goals, Paul suggests, like Basdeo, that Robin Hood tales of "a preindustrial age . . . are ill-equipped to critique the extra-state governance of advanced liberal capitalism” (49). Overall, Paul's essay provides a thoughtful commentary on the ways in which social democracy was more likely hindered rather than advanced by this popular television program.

Noel Brown, author of "Individualism and National Identity in Disney's Early British Films," ${ }^{16}$ also investigates the mid-century representation of Robin Hood in the Disney film The Story of Robin Hood and His Merrie Men, produced and filmed in Britain in 1952. Like Gossedge and Paul, Brown emphasizes Robin Hood's American trait of individualism. Robin Hood and his Merrie Men is part of a series of live-action Disney movies set and filmed in Britain and released between the early 1950s and the late 1960s. ${ }^{17}$ The purpose of Brown's analysis is twofold: to determine the process by which Disney attempted to negotiate "a mid-Atlantic path between British and North American customs and ideologies" (189) and to determine the success of this endeavor. Although created for a young audience, Brown argues that "far from being simple and vacuous exploitation releases, these apparently artless and undistinguished productions reflect complex ideologies of freedom and individualism" (189). Additionally, they are also "inherently liminal" (189) and occupy a space between the continents, made in Britain for a largely American audience by an American filmmaker, but also box office successes in Britain as well.

\footnotetext{
${ }^{15}$ Andrew Paul, "Reassessing Blacklist Era Television: Civil Libertarianism in You Are There, The Adventures of Robin Hood, and The Buccaneers," American Studies 54, no. 1 (2015): 29-52.

${ }^{16}$ Noel Brown, “Individualism and National Identity in Disney’s Early British Films,” Journal of Popular Film and Television 43 (2015): 188-200.

${ }^{17}$ Other Disney films discussed in Brown's essay include The Sword and the Rose (1953), Rob Roy, The Highland Rogue (1953), Kidnapped (1960), and The Fighting Prince of Donegal (1966).
} 
Brown's analysis begins with an assertion that Disney's Robin Hood narrative emphasizes "tension points within British national identity" (194), a contrast between two antithetical forms of Englishness. The heroes, most notably Robin Hood, the Merrie Men, Marian, and King Richard, represent a number of idealized characteristics including "freedom of movement and expression," courage, a home in the idealized greenwood, "self-reliance," "camaraderie," and "egalitarianism," i.e., quintessential American characteristics (194). On the other hand, the villains, Prince John and the Sheriff of Nottingham, represent the "undesirable qualities" of "cruelty, perfidiousness, cowardliness, rule by fear and intimidation ... ostentation ... and ... imperialistic oppression" (194). Brown concludes his analysis by arguing that the Disney project overall, and Robin Hood and his Merrie Men (1952), in particular, "colonize" British narratives and landscape into stories of American individualism (190). Brown is most disturbed by the "lone [authority] figure, a charismatic and galvanizing leader" that, he claims, represents American "individualism" as the "antithesis" of "collectivism" (191). Overall, he argues that rather than charting a "middle path," these films "correspond with North America's projected ideals of the 1950s and 1960s: democracy, responsibly small-scale capitalism, freedom, close affinity with the land, and mistrust of Big Government, high taxes, and advanced industrialization" (192).

The final essay featuring film analysis is Valerie B. Johnson's article, "Ecomedievalism: Applying Ecotheory to Medievalism and Neomedievalism." ${ }^{18}$ Johnson focuses on three iconic visual texts (two American films and one BBC series) spanning seventy years, and as her title suggests, Johnson demonstrates ways in which studying neomedievalist texts "through the bifurcated lens of ecocriticism and ecomaterialism" (31) enhances recognition of the inherent romantic fantasies about the Middle Ages that are often a part of neomedievalism. In her analysis of The Adventures of Robin Hood (1938), Robin Hood (2010), and the BBC series Robin Hood (2006-09), Johnson narrows her focus to the forest, Robin Hood's iconic greenwood, explaining that "[n]eomedieval texts ... deploy environmental descriptions and language to develop a sense of an authentic medieval setting . . . yet little critical attention is devoted to analyzing these methods from an ecological perspective” (31). The process of reading Robin Hood's greenwood through an ecomedieval lens "demonstrates the power of a medieval setting as a blank slate for modern fantasy" (33), which in turns reminds the viewer that these film forests are constructed set-pieces which provide the illusion of a pristine greenwood, "a rhetoric of greenery" (34) rather than the historical reality of a greenspace cultivated and defined by landowners and political authorities. Johnson emphasizes the artificiality of the movie-set forest, an artificiality which, she argues, is erased by the film-making process, so that the audience sees a fantasy, neomedieval, and primeval greenwood setting rather than an authentic constructed forest space in which outlaws and other outcasts hide from or prey upon wealthy noblemen and starving peasants as they hunt (or poach) royal deer. Since, as Johnson explains, each successive Robin Hood film builds upon the vivid greenwood established in earlier films, the pristinely beautiful constructed greenwood becomes "a visual metonymy for Robin Hood" (38). As she concludes Johnson

\footnotetext{
${ }^{18}$ Valerie B. Johnson, “Ecomedievalism: Applying Ecotheory to Medievalism and Neomedievalism,” Studies in Medievalism XXIV: Medievalism in the Margins, ed. Karl Fugelso, Vincent Ferré, and Alicia C. Montoya (Woodbridge, UK: D. S. Brewer, 2015), 31-37.
} 
reminds us that the erasure of the human habitation in "ecologically diverse" and "politically constructed" woodlands in favor of the neomedieval quest for the "inauthentic authenticity," a "primeval . . . untouched wilderness" (37) is a fantasy that slips easily into reality for the consumers of Robin Hood productions. Johnson argues convincingly that "[e]comedievalism allows us to see that these networks and relations exist, that they are not 'natural,' and that the facts of our environment are as much a narrative as our own stories” (37).

The writers reviewed here have studied a range of Robin Hood from a corpus of nearly five centuries of material and have contributed to the body of Robin Hood studies in important and often quite original ways. They have grappled with the ways in which these transgressive (and some not transgressive enough) texts reveal cultural and social tensions that may often encourage political resistance. The diversity of theoretical perspectives employed and primary texts studied aptly demonstrate the rhizomatic nature of the matter of Robin Hood and Robin Hood studies.

19 Jacques Le Goff, “The Wilderness of the Medieval West,” in The Medieval Imagination, trans. Arthur Goldhammer (Chicago: University of Chicago Press, 1998): 47-59, quoted in Johnson, 35. 


\section{BIBLIOGRAPHY}

Basdeo, Stephen. "Radical Medievalism: Pierce Egan’s the Younger's Robin Hood, Wat Tyler, and Adam Bell.” In Leeds Working Papers in Victorian Studies, Vol 15: Imagining the Victorian, edited by Lauren Padgett and Stephen Basdeo, 49-65. Leeds: LCVS, 2016.

Brown, Noel. "Individualism and National Identity in Disney's Early British Films." Journal of Popular Film and Television 43 (2015): 188-200.

Crook, David. "The Novelist, the Heiress, the Artisan, and the Banker: The Emergence of the Robin Hood Legend at Edwinstowe, c. 1819-1849." Transactions of the Thoroton Society of Nottinghamshire 119 (2015): 169-81.

Duncan-Jones, Katherine. Ungentle Shakespeare: Scenes from His Life. London: Thomson Learning, 2001.

Gossedge, Rob. “We Are Robin Hood': The Outlaw Tradition in Contemporary Popular Culture.” In Medieval Afterlives in Contemporary Culture, edited by Gail Ashton, 251262. London: Bloomsbury, 2015.

Howard, Jean. "Political Fortunes of Robin Hood on the Early Modern Stage." In Forms of Association: Making Publics in Early Modern Europe, edited by Paul Yachnin and Marlene Eberhart, 272-288. Massachusetts Studies in Early Modern Culture. Amherst: University of Massachusetts Press, 2015.

Johnson, Valerie B. "Ecomedievalism: Applying Ecotheory to Medievalism and Neomedievalism.” In Studies in Medievalism XXIV: Medievalism in the Margins, edited by Karl Fugelso, Vincent Ferré, and Alicia C. Montoya, 31-37. Woodbridge, UK: D. S. Brewer, 2015.

Kaufman, Alexander L. “A Desire for Origins: The Marginal Robin Hood of the Later Ballads.” In Studies in Medievalism XXIV: Medievalism in the Margins, edited by Karl Fugelso, Vincent Ferré, and Alicia C. Montoya, 51-62. Woodbridge, UK: D. S. Brewer, 2015.

. “John Mair’s Historiographical Humanism: Portraits of Outlaws, Robbers, and Rebels in his Historia Maioris Brianniae tam Angalie quam Scotiae (History of Greater Britain). Erratio 19 (2015): 104-18.

Knight, Stephen. The Politics of Myth. Manchester: University of Manchester Press, 2015. . Reading Robin Hood: Content, Form, and Reception in the Outlaw Myth. Manchester Medieval Literature and Culture Series. Manchester: Manchester University Press, 2015.

Knight, Stephen and Thomas Ohlgren, ed. Robin Hood and Other Outlaw Tales. TEAMS Middle English Texts Series. Kalamazoo, Medieval Institute Publications, 1997.

Le Goff, Jacques. "The Wilderness of the Medieval West." In The Medieval Imagination, translated by Arthur Goldhammer, 47-59. Chicago: University of Chicago Press, 1998.

Marshall, John. Review of Reading Robin Hood: Content, Form, and Reception in the Outlaw Myth, by Stephen Knight. Arthuriana 26, no. 2 (2016): 141-143

Paul, Andrew. "Reassessing Blacklist Era Television: Civil Libertarianism in You Are There, The Adventures of Robin Hood, and The Buccaneers.” American Studies 54, no. 1 (2015): 2952.

Quamby, Kevin A. “'Bardwashing' Shakespeare: Food Justice, Enclosure, and the Poaching Poet.” Journal of Social Justice 15 (2015): 1-21. 
Rahman, Sabina. “Knight: Reading Robin Hood.” Medievally Speaking, 6 November 2015, http://medievallyspeaking.blogspot.com/2015/11/knight-reading-robin-hood.html. 